\title{
Autosomal recessive inheritance of cutaneous asthenia in a dog - case report
}

\section{Astenia cutânea autossômica recessiva em cão - relato de caso}

\author{
Pedro Henrique França Saigali ${ }^{1}$; Paulo Henrique de Affonseca Jardim²; \\ Eric Schmidt Rondon ${ }^{3 *}$
}

\section{Highlights:}

Cutaneous asthenia (CA), in dogs, is caused by autosomal dominant inheritance.

This report describes a clinical case of canine CA of hereditary recessive origin.

Autosomal recessive inheritance must be considered for CA in dogs. Healthy parents can generate dogs with CA.

\begin{abstract}
Cutaneous asthenia (CA) or Ehlers-Danlos Syndrome, in dogs, is a rare hereditary syndrome caused by autosomal dominant inheritance that causes collagen synthesis failure and leads to hyperextensibility and cutaneous fragility. This report describes a clinical case of canine CA of hereditary recessive origin, hitherto proven for other species, in an animal born from inbreeding healthy parents. A one-year-old female Maltese dog received clinical and surgical care for a cutaneous wound after a hygienic bath. The clinical history revealed the occurrence of other injuries that were caused by minor trauma and the consanguinity of the patient. During wound cleaning, the trichotomy and removal of an adhesive tape that was fixed to the skin generated new lacerations, which led to clinical suspicion of CA. CA was confirmed by calculating the cutaneous extensibility index (CEI), which was $22 \%$, higher than the normal limit for the species $(14.5 \%)$. The skin biopsy confirmed the clinical diagnosis, and the wound of the animal was treated routinely and healed clinically. Both dominant and recessive patterns have been well documented in cats; however, in dogs, only the dominant form has been reported in the literature. Our findings demonstrate that canine CA may result from autosomal recessive inheritance, and CA must be considered during diagnostic clinical approaches and breeding selections.
\end{abstract}

Key words: Collagen. Ehlers-Danlos Syndrome. Wounds.

\section{Resumo}

A astenia cutânea (CA) ou Síndrome de Ehlers-Danlos, em cães, é uma síndrome hereditária rara, causada por gene autossômico dominante que resulta em falha na síntese de colágeno levando à hiperextensibilidade e à fragilidade cutâneas. O objetivo deste trabalho é relatar a existência de astenia cutânea canina de origem hereditária recessiva, até agora comprovada para outras espécies, a partir da descrição de um caso clínico de CA em um animal nascido de união consanguínea de pais saudáveis. Uma cadela Maltês, com um ano de idade, recebeu atendimento clínico-cirúrgico por apresentar uma

\footnotetext{
${ }^{1}$ Discente do Programa de Residência em Clínica Cirúrgica de Pequenos Animais, Departamento de Medicina Veterinária, DMV, Faculdade de Medicina Veterinária e Zootecnia, FAMEZ, Universidade Federal de Mato Grosso do Sul, UFMS, Campo Grande, MS, Brasil. E-mail: pedro.saigali93@gmail.com

2 Discente de Doutorado do Programa de Pós-Graduação em Ciências Veterinárias, CIVET, DMV, FAMEZ, UFMS, Campo Grande, MS, Brasil. E-mail: paulo.jardim@ufms.br

3 Prof., CIVET, DMV, FAMEZ, UFMS, Campo Grande, MS, Brasil. E-mail: itacron@gmail.com

* Author for correspondence
} 
ferida cutânea após um banho higiênico. A história clínica revelou a ocorrência de outros ferimentos provocados por pequenos traumas e a origem consanguínea da paciente. Durante a limpeza da ferida, a tricotomia e a remoção de uma fita adesiva fixada à pele geraram novas lacerações levantando à suspeita clínica de astenia cutânea, confirmada pelo cálculo do índice de extensibilidade cutânea (CEI) que resultou em $22 \%$, valor superior ao limítrofe de normalidade para a espécie $(14,5 \%)$. A biopsia cutânea confirmou o diagnóstico clínico. A ferida do animal foi tratada rotineiramente resultando em cura clínica. Tanto as formas dominante e recessiva foram bem documentadas em gatos; entretanto, em cães, somente a forma dominante havia sido descrita pela literatura. Concluiu-se que a astenia cutânea canina pode advir de herança autossômica recessiva e isto deve ser considerado durante a abordagem clínica visando o diagnóstico e a seleção racial.

Palavras-chave: Colágeno. Feridas. Síndrome de Ehlers-Danlos.

\section{Introduction}

Cutaneous asthenia (CA) is a complex of rare hereditary defects, mainly caused by collagen synthesis failure, and hyperextensibility and cutaneous fragility are the most common clinical signs (Paciello, Lamagna, Lamagna, \& Papparella, 2003; Andrade et al., 2008). Although it was first described in dogs in 1943, its pathogenesis remains poorly understood (Halper, 2014).

The clinical signs and history of inexplicable dermal injuries are based on initial diagnoses, which can be confirmed by quantifying the cutaneous extensibility index (CEI). CEI is the ratio between two measures, the height of the dorsolumbar skin under traction and the body length from the occipital crest to the base of the tail, multiplied by 100 (Patterson \& Minor, 1977; Paciello et al., 2003). The normal range in dogs varies from 6 to $10 \%$ (Paciello et al., 2003) or $14.5 \%$ (Patterson \& Minor, 1977). A skin biopsy can be used to confirm the presumptive diagnosis when a reduction in the number of collagen fibers and an incidence of structural disorders are observed (Patterson \& Minor, 1977; Dokuzeylül et al., 2013). In humans, CA is also known as Ehlers-Danlos syndrome and consists of ten different disorders that are classified according to clinical, biochemical, and genetic forms (Ducatelle, Hoorens, Charlier, Cornelissen, \& Calus, 1987). Both dominant and recessive patterns have been well documented in cats; however, in dogs, only the dominant form has been reported in the literature (Hegreberg, Padgett, Gorham, \& Henson, 1969; Minor et al., 1983). Herein we report a clinical case of CA, which is, in fact, a rare disease in dogs. Moreover, we report the case of a bitch with CA-free parents who showed for the first time that recessive inheritance occurs in dogs, as was previously reported for other species.

\section{Case Report}

A one-year-old female Maltese dog who weighed $2.2 \mathrm{~kg}$ was examined for a neck skin injury. Her clinical history revealed that the lesion had arisen about 10 days after a hygienic bath and that, on other occasions, the patient had presented similar injuries after minor domestic trauma. The owner confirmed that the patient was born from mating a father and daughter who were also owned by him, and that the parents had healthy skin.

The general physical examination did not reveal changes in vital signs. However, on skin inspection, a cutaneous laceration, of approximately $3 \mathrm{~cm}$ on its largest axis, was observed in the ventral region of the neck, at the height of the fifth cervical vertebra. A local dressing was performed under chemical containment, which used tramadol hydrochloride, midazolam, and propofol. During trichotomy, a delicate friction from the removal of an adhesive tape that attached the venous catheter to the skin, at the distal region of the right tibia, produced new cutaneous lacerations (Figure 1). 


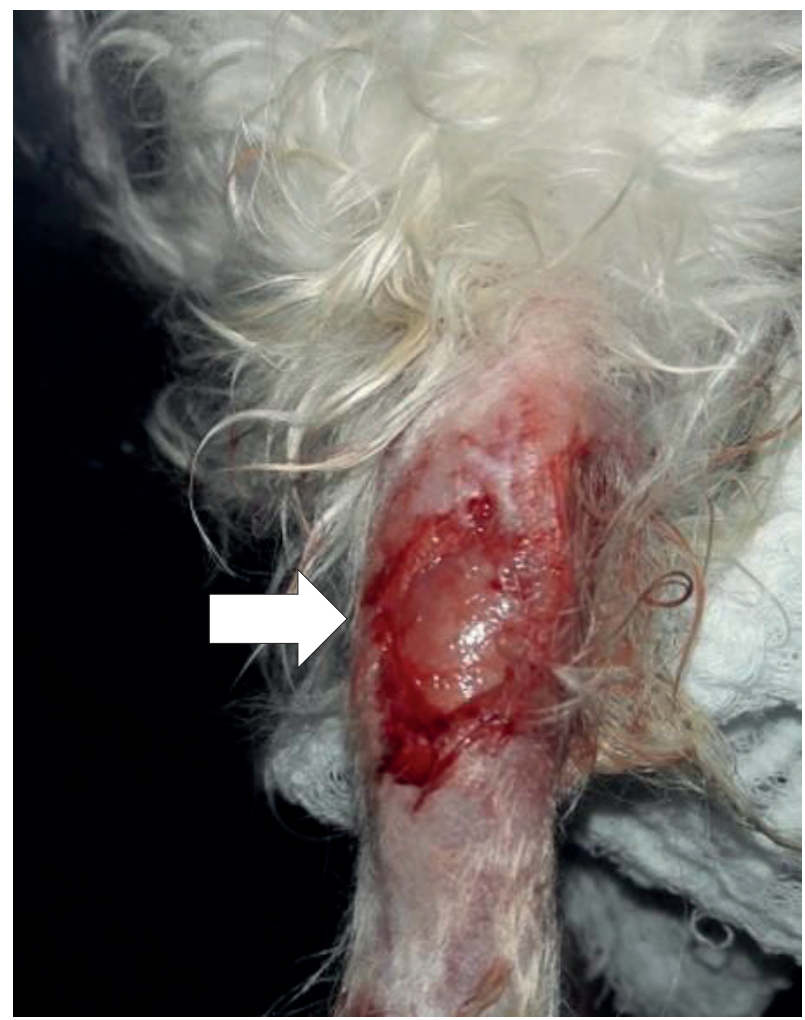

Figure 1. Cutaneous laceration (white arrow) in the distal cranial region of the right tibia caused by a delicate friction from the removal of an adhesive tape that attached the venous catheter to the skin. Canine, Maltese, female, one-yearold.

Then, we decided to determine the CEI by measure the height of the dorsal fold (A) and the distance from the occipital crest to the tail (B). The CEI was calculated from the formula CEI $(\%)=$ $\mathrm{A} / \mathrm{B} \times 100$. In the case served, these values were $\mathrm{A}$ $=6.2 \mathrm{~cm}$ and $\mathrm{B}=28.0 \mathrm{~cm}$, which resulted in a CEI of $22 \%$.

As a routine procedure, venous blood samples were collected to determine total blood count and alanine aminotransferase (ALT), creatinine, and total protein levels.

The animal was kept under anesthesia, for skin biopsies of the dorsum and injured neck. The samples were conserved in a $4 \%$ formalin solution and sent for histopathological analysis. The skin was sutured using 3-0 mononylon in a standard separate single suture pattern. A local dressing with $0.9 \%$ $\mathrm{NaCl}$ solution, followed by neomycin ointment and systemic cephalexin and dipyrone, were prescribed.
The use of an Elizabethan necklace and trauma avoidance were strongly recommended. After ten days, the owner was contacted to inquire about the state of the animal.

\section{Results and Discussion}

Initially, during clinical and surgical care, a traumatic cutaneous laceration was suspected, which should be treated with debridement and wound cleaning under anesthesia. However, the trichotomy and adhesive tape removal were found to produce new lesions, and a base disease was considered; despite its rare occurrence, occurrence of CA became a plausible hypothesis (Paciello et al., 2003; Andrade et al., 2008). The calculated CEI was $22 \%$, which is above the normal limit for dogs even after considering differences between references: 10\% (Paciello et al., 2003) or $14.5 \%$ (Patterson \& Minor, 1977). The biopsies confirmed 
the clinical diagnosis, as they revealed a decreased amount of collagen fibers and morphological changes in the remnants (Figure 2), and these histopathological findings are compatible with CA (Andrade et al., 2008; Dokuzeylül et al., 2013). Clinical and hematological investigations did not reveal changes in other tissues in this patient, although it is known that collagen synthesis failure may lead to changes in other tissues that cause pathologies such as herniation, arthropathy, and ophthalmic diseases (Menezes, Moraes Faria,
Paulo, Fleury, \& Brito, 2007; Andrade et al., 2008; Hansen, Foster, Burrows, Mackie, \& Malik, 2015). The clinical follow-up confirmed that there is no specific therapeutic management for $\mathrm{CA}$, and only injury care and management recommendations are available for domestic accident prevention (Hansen et al., 2015). The cutaneous injuries showed an adequate response to the treatment, since skin integrity was restored ten days after the incident, which is the usual time for second intention healing in dogs (Bohling \& Henderson, 2006).

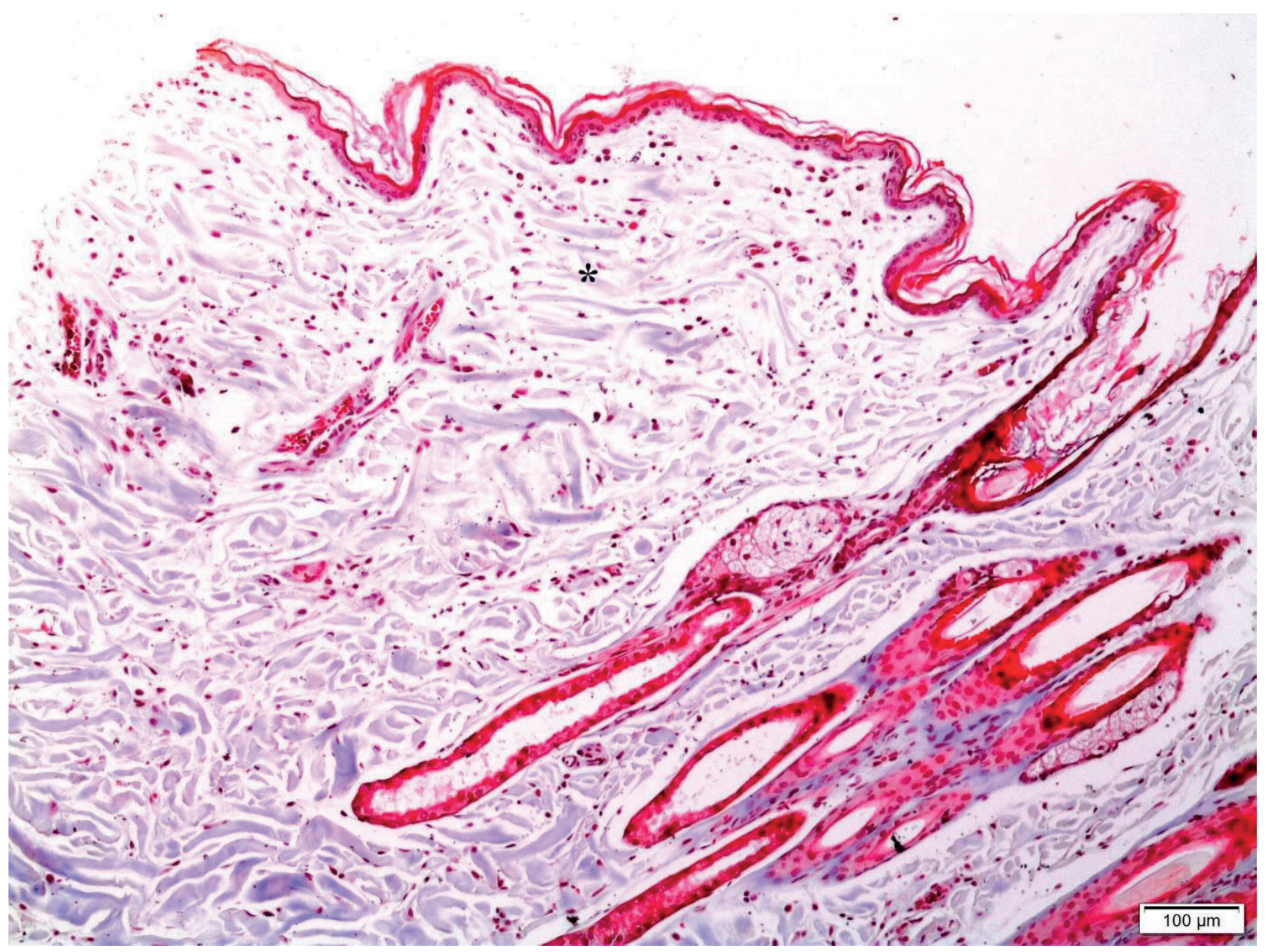

Figure 2. Photomicrographs of skin samples showing collagen dysplasia (Cutaneous asthenia). In the superficial dermis, there is a decrease in the amount of collagen fibers $(*)$ and changes in the morphology of the remnants. The fibers have different sizes, different directional dispositions and increased spaces between them. Masson's trichrome stain, x10, Bar $=100 \mu \mathrm{m}$. Canine, Maltese, female, one-year-old. 
Several autosomal recessive diseases are more easily inherited from inbred patients (Woods et al., 2006). Previous studies have not revealed a racial predisposition to $\mathrm{CA}$ for Maltese (Paciello et al., 2003). In dogs, CA is believed to be due to an autosomal dominant gene (Minor et al., 1983); however, considering that the patient was born from a consanguineous cross-breeding of clinically CAfree progenitors, it can be stated that the CA was inherited by recessive gene expression, as has been described for other species (Halper, 2014).

\section{Conclusion}

Canine CA may result from an autosomal recessive gene and must be considered during clinical diagnoses and breeding selections.

\section{References}

Andrade, S. F., Tostes, R. A., Sanches, O., Melchert, A., Nogueira, R. M. B., \& Valente, S.F. (2008). Astenia cutânea em gato (relato de caso). Ciência Animal Brasileira, 9(2), 524-528.

Bohling, M. W., \& Henderson, R. A. (2006). Differences in cutaneous wound healing between dogs and cats. The Veterinary Clinics of North America. Small Animal Practice, 36(4), 687-692. doi: 10.1016/j. cvsm.2006.02.001

Dokuzeylül, B., Altun, E. D., Özdogan, T. H., Bozkurt, H. H., Arun, S. S., \& Or, M. E. (2013). Cutaneous asthenia (Ehlers-Danlos syndrome) in a cat. Turkish Journal of Veterinary and Animal Sciences, 37(2), 245-249. doi: 10.3906/vet-1203-64

Ducatelle, R., Hoorens, J., Charlier, G., Cornelissen, F., \& Calus, A. (1987). A morphometric classification of dermatosparaxis in the dog and cat. Vlaams Diergeneeskundig Tijdschrift (Belgium), 56(2), 107117.

Halper, J. (2014). Connective tissue disorders in domestic animals. Advances in Experimental Medicine and Biology, 802, 231-240. doi: 10.1007/978-94-0077893-1_14
Hansen, N., Foster, S. F., Burrows, A. K., Mackie, J., \& Malik, R. (2015). Cutaneous asthenia (EhlersDanlos-like syndrome) of Burmese cats. Journal of Feline Medicine and Surgery, 17(11) 954-963. doi: $10.1177 / 1098612 \times 15610683$

Hegreberg, G. A., Padgett, G. A., Gorham, J. R., \& Henson, J. B. (1969). A connective tissue disease of dogs and mink resembling the Ehlers-Danlos syndrome of man: II. Mode of inheritance. The Journal of Heredity, 60, 249-254. doi: 10.1093/ oxfordjournals.jhered.a107983

Menezes, L. B. de, Moraes Faria, A. de, Paulo, N. M., Fleury, L. F. F., \& Brito, M. S. de. (2007). Hérnia perineal associada à colagenopatia em uma cadela. Acta Scientiae Veterinariae, 35(3), 377-379.

Minor, R. R., Lein, D. H., Patterson, D. F., Krook, L., Porter, T. G., \& Kane, A. C. (1983). Defects in collagen fibrillogenesis causing hyperextensible, fragile skin in dogs. Journal of the American Veterinary Medical Association, 182(2) 142-148.

Paciello, O., Lamagna, F., Lamagna, B., \& Papparella, S. (2003). Ehlers-Danlos-like syndrome in 2 dogs: clinical, histologic, and ultrastructural findings. Veterinary Clinical Pathology, 32(1), 13-18. 10.1111/j.1939-165X.2003.tb00306.x

Patterson, D., \& Minor, R. (1977). Hereditary fragility and hyperextensibility of the skin of cats. A defect in collagen fibrillogenesis. Laboratory Investigation; a Journal of Technical Methods and Pathology, 37(2), 170-179.

Woods, C. G., Cox, J., Springell, K., Hampshire, D. J., Mohamed, M. D., Mckibbin, M., Stern, R., Raymond, F. L., Sandford, R., Sharif, S. M. (2006). Quantification of homozygosity in consanguineous individuals with autosomal recessive disease. The American Journal of Human Genetics, 78(5), 889896. $10.1086 / 503875$ 
